\title{
Historical Material in Maurice Gee's The Fire-Raiser
}

\author{
Vivien van Rij
}

\section{The Nelson CENTRAL School Material AND F.G. GibBS}

Award-winning New Zealand novelist, Maurice Gee, once described the transposition into his fiction of Frank Sargeson's short story, 'An Affair of the Heart', as 'a straight steal' (van Rij 'Interview'). What follows is an examination of Gee's transpositions of historical material into The FireRaiser, the first of his five realistic novels for children.

The Fire-Raiser is recognisably located in Nelson, New Zealand in 1915 - characters replicate Nelson's historical figures, and explicit reference is made to real events. In fact Gee discovered much of the novel's material in the course of research he undertook to write his only non-fictional text, Nelson Central School: A History, which came about partly because in 1975 Gee shifted to Nelson with his wife (Margaretha) and young family. While Margaretha was employed as librarian at the Nelson Provincial Museum and as a part-time archivist at the Cawthron Institute, Gee cared for their two daughters. He supervised their leisure activity when they came home from Nelson Central School, and during school hours was free to write, completing over this period several novels for children and adults, including The Fire-Raiser in 1986.

Gee finished writing the school history in time for its centennial celebrations in 1978. Two newspapers (The Colonist and The Nelson Evening Mail) and memories of the school's ex-pupils provided sources of information for the history which also drew on the Nelson Provincial Museum's archival material, particularly the diaries of F. G. Gibbs, headmaster of Nelson Central School from 1894 to 1923. Shonadh Mann's biography of Gibbs, F. G. Gibbs: His Influence on the Social History of Nelson, 1890 to 1950 , was another important source. It too drew on Gibbs' diaries, interviews and memories. Nelson Central School: A History has been rightly described as unusually vivid and 'a major contribution to the history of education based on extensive oral research and Gee's sensitivity to social issues' (Wattie 197-98). 
That Nelson Central School is 'a social as well as a factual history' is noted by Gee in its preface (7). ${ }^{1}$ Indeed, Gee's comment seems to hint at what could be described as an almost fictional dimension to history, especially in terms of lived experiences in Nelson between 1878 and 1978 . By including the memories of Gibbs and other past teachers and pupils their voices, stories, playground rhymes, thoughts, feelings, and recall of daily events - Gee recreates school life as it might be represented in a novel. The reader therefore has access to the fun and discomfort of social gatherings, the affection and fear felt by pupils for their teachers, the kindness and cruelty of some teachers, individual compassion and mob prejudice, and the times of nationalist uncertainty yet patriotic complacency.

The school inspectors captured in Nelson Central School are on one level sympathetic to John Dewey's progressive model of teaching, and encourage experiential child-centred learning, but on another level conform to the traditional British model with its rote learning and corporal punishment. As Gee records it, W. C. Hodgson, Inspector of Schools for the Nelson Education Board from 1863 to 1893, typified the period's ambivalence. A believer in schools as 'humanizing agencies' (28), Hodgson expressed concern at the popularity of arithmetic, a subject he believed made 'fewer demands upon the imagination' (23), turning out 'young Gradgrinds' crammed full of nothing but 'hard facts' (28). Hodgson also 'held the rather disturbing opinion that [military drill] helped bring up a "readily obedient race" (23). Similarly two-sided is Gee's picture of the schoolteacher Miss M. Kitching. Remembered by past pupils as 'a dear soul, but very stern' (50) and as 'loved and respected' (51), she is differently described by one pupil in a playground rhyme:

Kitch, Kitch, the silly old bitch,

Goes to church on Sunday,

To pray to God

To give her strength

To whack the boys on Monday. (51)

In Nelson Central School, then, Gee pays heed to dates and events, and also to a subjective dimension which includes emotion, opinion, impression, and everyday trivialities. Of all the material used to such effect by Gee, none reveals so much about the times or the individual recording them as F. G. Gibbs' diaries. It is illuminating to examine Gee's treatment of these. 
Although the Nelson Central School story is tracked from 1878 to 1978 , the section devoted to the Gibbs period is longer and more vivid than any other. Gee notes in the Introduction, this is partly because 'the memories of older ex-pupils [ . . . ] were detailed and vivid' (7). Within the section on the Gibbs period, it is the headmaster, F. G. Gibbs who (alive in the memories of those who had known him) is most vividly depicted of all. Teaching briefly at Bridge Street School in 1887, Gibbs left at the end of the year, and was presented by the boys with a thermometer as a leaving present. From 1894 to 1923 Gibbs taught at Nelson Central School, gaining the reputation of being forward-thinking and knowledgeable. He established a cricket club, planted trees on Arbor Days in 1899 and 1900, and took the children on class trips.

Gibbs comes across as a liberal humanist, with wide-ranging interests across the arts, humanities, and sciences. Recalled as a philanthropist and an idealist, he seems to have had a larger-than-life personality. Gee records, for example, that Gibbs was fervently anti-jingoist and well known locally for defending a German music teacher against racist attacks during World War I. He describes Gibbs' subsequent reputation of being proGerman, unfair castigations of him as 'a dirty German Jew' and 'German Sausage', and the resulting nickname 'Sos' (49). Past pupils, their memories often quoted verbatim by Gee, speak glowingly of Gibbs, describing him as 'an outstanding teacher and headmaster' (5), 'a Renaissance man' (95), and 'a rotund little man, thick-set and bursting with energy' (49).

Within the section entitled 'The Gibbs Years, 1894 - 1923' Gee provides descriptions of Gibbs' numerous idiosyncrasies. Citing the Mann biography, Gee notes 'the attractive picture of the headmaster walking in the playground followed by a trail of children chanting their tables and spelling at him' who became known as 'Gibbs' Puppy Dogs' (43). He quotes the account of a Mr J. Grigg (ex-pupil and later teacher) of how Gibbs, performing a 'bell-ringing ritual', at 8.55 am would 'sail along the front fence on his motor-cycle and the first boy to see him would race to ring the bell' (43). Recording the recollections of Mr J. Savage (another ex-pupil and teacher), Gee notes the folding magnifying glass, thermometer, and tuning fork that Gibbs, a keen scientist, carried in the 'innumerable pockets in his waistcoat' (43). And Gee describes Gibbs' biology lessons on 'the bones of the body' using a skeleton known as 'a French lady': '[Gibbs] had obtained a skeleton said to be a French lady and this was kept in a 
cupboard and brought out for lessons. Later it was moved to the belfry. Gibbs would send a boy to fetch it when it was needed. From this the boys learned the bones of the body' (43).

However, the portrayal of Gibbs is interspersed with stringent criticisms revealing the headmaster's less appealing side. Depictions of his various battles with the Town Schools Committee from 1896 to 1899 hint at Gibbs as cocky and aggressive, a picture suggested by Gibbs' own words. According to Gibbs 'a cheeky letter' (39) was sent on one occasion to the Committee, and on another a 'short but sweet reply' (41), and upon winning a battle Gibbs vengefully said, 'I had my innings' (41). Gibbs' involvement in a dispute over riparian rights to swimming holes on the Maitai River in 1916, and the ensuing court battle against landowners, a Mrs Richardson and her two daughters, emphasise his petty vindictiveness, as does an ex-pupil's recollection of an incident involving the Richardsons' hydraulic ram: 'I have seen Mr Gibbs deliberately stick little bits of wood or leaves into the flapper of the valve to jam the mechanism. He did it in front of the boys and thought it was clever. I thought it was a dirty thing to do' (49).

Gibbs' nastiness is apparent in his attitude to children. The inclusion of extracts from his diary reveals his brutality: 'When Mr Worley was sick [Gibbs] took his boys - "horrible young rogues" - and took the infants "40 brats" - when Miss Snart was sick. With Worley's boys he had to "use the stick a lot"' (16). Gee further records: 'Jickell gave me a cheeky answer [. . . ] so I took him in and thrashed him immediately. This has had a good effect on him and all the others' (36). Ex-pupils vividly recall Gibbs' use of corporal punishment, and his lack of justice, humour, and self-awareness. One remembers spectators and fighters being strapped by Gibbs, the thrashing given to boys wrongly accused of kissing a girl, and the fact that 'Gibbs could not see he had done anything wrong' (50). A poem by another ex-pupil displays a clownish side to Gibbs that caused him to react violently:

Denne's Hole is a lovely place,

It gives much pleasure to every face.

When lessons are done, away we run

To swim and dive and have lots of fun,

And old Sos Gibbs in his neck-to-knees

Looks like a beer barrel standing at ease (49). 
Apparently 'not amused' by the poem, Gibbs 'took the boy in and strapped him so severely his hands were swollen for a week' (50). Hence Gee offers a balanced and qualified opinion that takes account of both the positive and negative sides of Gibbs: 'Although most of [Gibbs'] pupils remember him affectionately - "a fine old character, with exaggerated qualities" - to others he was a "dreadful little autocrat" (50).

In Nelson Central School Gee depicts subsequent years, other personalities, and the 1978 centennial, but it is Gibbs who remains in the reader's mind. Although much briefer than Mann's biography, Gee's history gives a more complicated view. Where Mann emphasised Gibbs' public persona, Gee emphasises not only that, but also the private, less pleasant individual, and different perspectives (his own included), thus constructing a portrait of Gibbs that is rounded, authentic and balanced.

\section{THE NELSON MATERIAL AND THE NOVEL}

Nelson Central School was published in 1978. Sometime later, as he has recalled, Gee was asked by Ginette McDonald to write a children's television serial. He wrote five scripts then quickly turned them into a novel which 'came out at the same time as the television serial' (van Rij 'Interview') in 1986. Set in 1915 during World War I, it depicts four child protagonists and their headmaster who set out to solve the mystery of the fires that occur in the township of Jessop, and to pursue the arsonist (Edgar Marwick). Blamed for the drowning of his sister in childhood, and subjected by his parents to corporal punishment, the adult Marwick is unbalanced, as is his mother. Their battle with the headmaster and children over riparian rights to water holes on their land, and Marwick's fires echo on a smaller scale the battles of the world at war. Gee has acknowledged Nelson Central School as a source of The Fire-Raiser, and the quasi-Dickensian Gibbs and the 'firebug' as having, in effect, almost fictional dimensions:

The idea for The Fire-Raiser began when I wrote a history of the local school and came across one of the early headmasters - an outstanding character in Nelson's history. Then there was a bricklayer who was a firebug. He claimed at his trial that he burnt down buildings to make work for the unemployed. So I had these two characters almost ready-made and mixed some children in with them to create the story. (O’Brien 113) 
Perhaps the forest fire in Nelson's Hira Forest and Maitai Valley in February 1981 further influenced Gee who has acknowledged seeing it at 'close hand' (Boyd 167). Possibly reminded of material uncovered in writing Nelson Central School, particularly Johann Blecher's fire-raising escapades in the nineteenth century, Gee may have recognized arson as a theme for a good story. In considering the influence of these sources on Gee's writing, this article now makes a series of comparisons between them and The Fire-Raiser.

Blecher's arson was reported in Nelson newspapers between 1892 and 1894, and was recorded in a 1957 issue of Journal of the Nelson Historical Society in an article entitled 'An Early Incident' by L. E. Baigent. Having observed the demolition of a brick building at 130 Rutherford Street, Nelson, Baigent remembered its occupant of sixty-five years earlier 'Blicker' ( properly Blecher), a bricklayer and plasterer, and immigrant of German extraction. He recalled Blecher's fires and the damage they caused, and Blecher as 'a very secretive, morose type', and commented: 'Our master-bricklayer, over the years, became more and more a recluse; more and more morose; more and more difficult to approach without evoking tirades against the community in general' (Baigent 14-15).

As Gee recorded in Nelson Central School, Blecher set light to several buildings in Nelson, including stables, a bakery, and schools. On one occasion police found stacked wood and sacking soaked in kerosene. The fires evidently sent their glare into the night sky, and were signalled by the fire bell. They were attended, sometimes unsuccessfully, by a valiant brigade, and caused much disruption, especially to the school's staff and pupils who had to be relocated. The obviously unstable Blecher believed himself to be trying to create work for the unemployed. When finally caught and arrested by a Constable McGrath, he was sentenced to imprisonment with hard labour.

Similarities between the fire-raising of Blecher and Marwick in the novel are obvious, with Gee apparently basing his depiction of Marwick on Blecher. Like Blecher, Marwick is morose, reclusive, aggressive, and unbalanced, and burns stables, a bakery, and almost a school. He even uses materials similar to those reportedly used by Blecher - cotton waste and rags, a crowbar, and benzene carried in a sack. Paralleling Blecher's fires, Marwick's fires light up the night sky, and are signalled by bells - the fire bell and the school bell. Like the historical fire brigade, the fictional fire brigade is not always able to control the fires, which cause much 
disruption. Where Blecher was led off to imprisonment by Sergeant McGrath, Marwick is led off, presumably to imprisonment, by Sergeant McCaa.

However, it is Gee's use of F. G. Gibbs from the school history as the artistic model for Thomas Hedges in The Fire-Raiser that is most interesting. Where Gibbs was teaching headmaster of Nelson Central School, Thomas Hedges is teaching headmaster of Jessop Main School. (Jessop is simply another name for Nelson - both towns feature lime trees, willows and a river.) Moreover, Gibbs and Hedges have in their schools barefoot, poorly clad children, some of whom belong to a gang called 'Port Rats'. Like Gibbs, Hedges is a bachelor.

From Nelson Central School we discover that Gibbs' wide-ranging interests across the arts, humanities and sciences carried over into his teaching. As Gee has commented, Gibbs was 'a sort of marvellous headmaster, a man of so many parts that it is almost impossible to enumerate them. Gibbs was interested in everything' (van Rij 'Interview'). Similarly Hedges has interests in the arts, humanities, and sciences that inform his teaching and outlook on life. Furthermore, Gibbs taught informal lessons in the local observatory, the school history reveals: 'When the observatory opened in Alton Street the senior boys went over with Gibbs on the longest and shortest days and had informal talks on astronomy, and [...] ] were shown "Venus at its brightest" and "two large sunspots"' (43). In The Fire-Raiser Hedges, too, teaches informal lessons at the nearby observatory: 'He left Phil at the telescope for another ten minutes. Soon the boy began asking sensible questions. Drawing him away at last, Hedges said, "You can come up at night. I'll show you Mars. And Venus"” (104). ${ }^{2}$

Idiosyncratic detail, fondly remembered in the school history, is re-used in the novel. Recalling Gibbs' bitten ear, Hedges has an ear 'mauled as though by a cat' (21). Exactly replicating Gibbs' teaching aids, Gee equips Hedges with a tuning fork, magnifying glass, and thermometer. Moreover, Gee appropriates Gibbs' skeleton to enable Hedges to teach biology in a similarly entertaining way. Like Gibbs' skeleton, Hedges' skeleton has a female persona. In Chapter Two it is viewed by the boys as they remove it from the school belfry's cupboard: '[Noel] opened the cupboard and [he and Phil] looked at Miss Perez. She glimmered at them, smiling, with her head bent in a regal way. Her slender feet were in line with their knees, 
her hands, palm up, at her waist, seemed to offer, but the rest of her, so empty, seemed to want' (23).

The Fire-Raiser also draws on material in Nelson Central School for its 'swimming hole' episodes. In each account the swimming trip represents bliss. Each headmaster demonstrates likeable idiosyncrasies, encourages the children to practise swimming on the bank, tests the water temperature with his thermometer, and throws a tin lid into the water to provide a goal for diving. Each headmaster also becomes involved in a dispute with the owners of land surrounding the river who claim the waterholes as their own, with each enjoying a good fight and intent on winning. Both Gibbs and Hedges dismantle private property notices and persist in the swimming trips anyway.

In Gibbs' case the 'war with Mrs Richardson' led to Mrs Richardson's drastic action. As Gee records in the school history: 'She stole the boys' clothes while they were in the water, but Gibbs told them to dance naked round her house and Mrs Richardson quickly gave the clothes back' (49). The ensuing court proceedings resulted in a triumph for Gibbs, although that did not stop him blocking the Richardsons' hydraulic ram. In Hedges' case the waterhole dispute leads to the Marwicks' similar retaliation in The Fire-Raiser: 'The boy came running from the scrub. "Someone's taken our clothes"' (38). Hedges and his class approach the Marwicks: 'Hedges smiled. He liked a fight. [ ... ] "Where's my redskins? Where's my warrior boys? Come out. Do a dance for Mrs Marwick.” [ . . ] They began leaping up and down, flinging their skinny limbs and howling at the sky' (40). Mrs Marwick hastily returns the clothes. Later, continuing the war, Irene blocks Marwick's hydraulic ram.

For Gee the waterhole incident seems to have embodied Gibbs' complex personality - his mixture of intelligence, energy and breadth of vision, as well as his petty vindictiveness and aggression. Gibbs also had 'an ambivalent attitude to the war' (46). Gee notes in Nelson Central School Gibbs' dislike of jingoism, pomp and ceremony, and his defence of German music teacher Herr Lemmer against racist attacks. But Gee also records Gibbs' fascination with battles: 'In the Great War he could always be side-tracked into discussing tactics. [...] Gibbs would be so absorbed with his maps, marking the battle lines with flags, that lessons were forgotten' (46). Gibbs led classes in singing patriotic songs: 'Gibbs would come through the school to each class, strike the front desk with his [tuning] fork, and lead the boys in the 
singing of patriotic songs - Hearts of Oak and Rule Britannia' (43). And the School contributed to the Belgian Relief Fund and knitted socks for soldiers.

Hedges has a far less complex personality than Gibbs, but at the same time he has an ambivalent attitude towards war. Like Gibbs, he dislikes pomp, ceremony, and 'jingoistic huff and puff' (111), and defends a German music teacher (Lotte Stauffel) from anti-German attacks. However, he is also easily persuaded into leaving lessons to discuss war as he does in chapter two of the novel, relinquishing arithmetic to discuss the British capture of Neuve Chapelle which he plots on a wall-map 'pinned with flags in a crooked line' (22). Further recalling Gibbs, Hedges uses his tuning fork to lead the children in song: 'He took out his tuning fork instead and banged it on his desk and only began to simmer down when he heard its note' (20). Similarly, 'Heart of Oak' (27) and other patriotic songs are sung at school and during the pageant, whilst Mrs Chalmers contributes to the Belgian Relief Fund and Mrs Wix knits socks for soldiers.

Gibbs' complexity, it is hinted in Mann's biography, may have been partly due to his intense relationship with his mother. According to Mann, Mrs Gibbs was a strong-willed woman, widowed prior to the family's departure from England. By sheer determination she established a domicile in New Zealand and brought up her nine children single-handed. An early marriage proposal by F.G. Gibbs (to an unidentified woman) was turned down, and he devoted himself to his work and community service, and lived with his mother until her death. Gee notes that for the rest of his life Gibbs remained a bachelor living on in the family home.

Gee seems to have Mann's material in mind in depicting Hedges as a man who may have had a difficult relationship with an imperious female. In Chapter Two of The Fire-Raiser Hedges' suffering is suggested by his facial disfigurement: 'He was a square-built man with an ugly face: nose like plasticine dented by a thumb, eyes that went one this way, one that, but saw well enough, and mouth like a leather purse, full of crooked teeth. His skin was pitted from some childhood illness and one of his ears mauled as though by a cat' (21). Certainly in 1915 Hedges is dominated by the autocratic Mrs. Bolton who sees herself 'locked in battle with him, fighting for Christian behaviour, right belief of every kind' (25). Like Gibbs, Hedges is an atheist, middle-aged, and a bachelor. 


\section{GEE’S REFASHIONING OF THE NELSON MATERIAL}

However, Gee does not simply transpose characters and events from Nelson Central School to The Fire-Raiser in a straightforward fashion. For instance, the brutality Gibbs has demonstrated in his corporal punishment of children is more often expressed in the novel through Marwick rather than through the relatively inoffensive Hedges. And Gibbs' living arrangements with his mother are more closely replicated in the Marwicks' domestic life. Indeed, diary accounts and biographical detail about Mrs Gibbs might have provided a model for Mrs Marwick who is similarly strong-willed and autocratic, and who dominates a middle-aged bachelor son. Gee apparently takes Mann's account of the Gibbs family's immigration to New Zealand, when Gibbs would have been about ten, and gives it to an approximately ten-year-old Julia Marwick and her mother. Where the Gibbs family sailed from England minus Mr Gibbs, who died of illness prior to the departure date, Julia Marwick and her mother seem to have sailed from England without Julia's father (who goes unmentioned in the novel). By tempering Gibbs' character in his construction of Hedges, and by combining the dramatic elements in Blecher, the Richardsons, and Gibbs to form the Marwicks, Gee sets the rational Hedges and the irrational Marwicks against each other. Thus he reveals his interest in division, and, in simplifying the historical characters, hints at a symbolic dimension to The Fire-Raiser, and the theme of good versus evil.

Echoing Nelson during Gibbs' time (as documented in the school history), Jessop in the novel is redolent of war. But Gee gives a figurative dimension to the period's conflicts between traditional and liberal, and empire and nation. Where images connected to Gibbs have a more literal significance, those connected to Hedges become emblematic. Gibbs' tuning fork, magnifying glass, and thermometer suggest his interests and idiosyncrasies, but in relation to Hedges, these images connect him to the novel's themes. Associated literally with 'tuning', the tuning fork as a symbol is used by Hedges to harmonise himself and his class: it is when he hears its note that he simmers down. Similarly, Hedges' thermometer and magnifying glass that enable him in the scientific sense to measure and see, ironically emphasise a reluctance to acknowledge human nature's unpleasant side, as is apparent in chapter two of the novel: 'He was oppressed as well by a knowledge of meanness, cruelty and pain, all waiting round corners, but he never let that bother him more than a mild 
headache or a bit of heartburn would have. He believed one must carry on as though life were the happy thing it could be' (21).

Distinct differences in the appearances of Gibbs and Hedges suggest Gee's wish to acknowledge Gibbs' contradictions whilst showing that in the less complex character of Hedges these traits are controlled. Where Gibbs is rotund, and in the biography's photograph has a direct gaze, regular features, and is reasonably good looking, Hedges is square, cock-eyed and ugly. Ironically it is the facially perfect Gibbs whose rotundity seemingly suggests brutality, whilst the facially flawed Hedges, whose squareness suggests order, aspires to humanity. Although Hedges' face reflects an abusive past, he more often than Gibbs is relentlessly controlled. Where Gibbs expressed his anger by thrashing children, Hedges checks his impulse to use the strap on Noel and Phil: 'He strode to his table and took his strap and let it fall out to its full length. [ . . ] He rolled his strap and threw it in the drawer' (32).

Hedges' harmony and balance are suggested in that he seems to hear the Pythagorean 'music' of the stars. In Chapter Nine during an informal astronomy lesson with Phil he comments: 'When you look up there at night [ . . . ] you can hear a kind of harmony' (104). The idealised perception of the cosmos that distinguishes Hedges from his historical model seems to epitomise his inclination to confer order where none exists. In other words, Hedges possesses the creative imagination of the artist.

Gee's tendency to adopt yet transform material from Nelson Central School is obvious in his treatment of the waterholes which function as a link between the school and the Marwicks. In the school history there are three holes - 'Girlie's', 'Dene's' and 'Sunday'. In the novel there are only two - the aforesaid 'Girlie's' and (Gee's own name) 'Buck's'. Gee's concern with duality is therefore neatly encapsulated. For Gibbs the pools were just pools. But Gee's pairing and naming make them images of a divided whole. Thus in Chapter Three Buck's Hole is the scene of romance, excitement and adventure, whilst in Chapter Eleven Girlie's Hole is the scene of near drowning and death.

The beauty, desirability and co-operation of diverse features - red and white, coldness and warmth, speckled and clear, flow in and flow out - are what Hedges registers when he first contemplates Buck's Hole. At the same time the encircling frame of breathless suspension, and the run-on sentence and lack of verbs and therefore action at the centre of this extract, 
suggest tranquillity and peace. Hedges' epiphany reflects his inner harmony:

The loveliness of this pool took his breath away. It always happened. The sand and shingle, oatmeal coloured, with red pebbles, white pebbles, speckled ones and brown, strewn about like some Caliph's treasure, and the water with the clarity of air and the coldness of stone, and the mossy banks, the bush with caves of shadow, the flow in, brittle, pure, the flow out, smooth as glass, and the green deeps, with the river floor somehow warm at the bottom - it held him in a moment of delight. (35-36)

Hedges' battle with the Marwicks over riparian rights further exemplifies Gee's investment of historical material with an emblematic dimension. As described in Nelson Central School, the waterhole dispute between Gibbs and the Richardsons led to a vicious court battle, with Gibbs unleashing his fury in, for instance, his use of corporal punishment. The Fire-Raiser's battle, however, is experienced less emotionally by Hedges, and it is Marwick who becomes aggressive. Even in the fight between Hedges and Marwick, Hedges exercises restraint. Gee's depiction of this fight in comic terms, and Hedges' deliberateness of action and selfawareness, suggest his unwillingness to allow passion to dominate. Whilst resorting to the physical, Hedges, in contrast to Gibbs, suppresses anger and remains controlled:

Hedges took off his jacket. He folded it and laid it on the ground. He unfastened his watch from his waistcoat and put it on top of the jacket. Then he faced Marwick. He put his left leg forward and doubled his fists and stood waiting. There was something comic in it, he knew. (129)

Gee refashions history in a similarly emblematic way in depicting the Marwicks. He conflates the villainy of Johann Blecher, the Richardsons, and Gibbs, to form the characters of the Marwicks who are more evil than any single character in Nelson Central School. Gee then sets them against Hedges with his ideals of balance and harmony. Furthermore, where Blecher was a German immigrant bricklayer and working class, and where the Gibbs family were English middle class and landed gentry, the Marwicks are English, and of upper class extraction having associated with aristocracy. In addition, they have enjoyed a prominent social position in Jessop society until tragedy struck, with the drowning of Lucie (their daughter), and their subsequent material and moral decline. 
Differences between the sea voyages of the Gibbs and Marwicks are also interesting. The Gibbs family sailed from England in April of 1877 when Gibbs was ten (Mann 6-10). As estimated from the novel's detail, the two Marwicks would have sailed in about 1855, with Julia aged approximately ten. 3 Gee has evidently adapted his source material to allow Mrs Marwick's memories of the voyage to be of herself at much the same age as the four child protagonists, whilst being consistent with the novel's World War I setting. That Gee gives Mrs Marwick a childhood allows Kitty to empathise when she hears her recollections in Chapter Eight.

Thus Gee provides an insight into the suffering underpinning Mrs Marwick's brutal treatment of her son. The parents' corporal punishment of Edgar Marwick, and his appetite for fire make the Marwicks emblems of fatally unrestrained passion, at the opposite end of the spectrum to Hedges who stands for harmony and control. Hence Gee strips the historical figures and situations of their moral and psychological complexity to make Hedges more thoroughly good, and the Marwicks more thoroughly evil. Together the Marwicks and Hedges represent tendencies that to varying degrees exist in all of the novel's characters. They reveal Gee's ideal in writing for children of creating a balance of antitheses, yet one in which the use and adaptation of the Nelson historical material ensure that evil is interwoven with good and held firmly under control.

\section{WORKS CITED}

Baigent, L. E. H. 'An Early Incident'. Journal of the Nelson Historical Society, 1/2 May, 1957.

Boyd, Brian. 'Maurice Gee/Interviewed by Brian Boyd'. In the Same Room: Conversations with New Zealand Writers. Eds. Elizabeth Alley and Mark Williams Auckland: Auckland University Press, 1992.

Gee, Maurice. The Fire-Raiser. Auckland: Puffin Books, 2003.

Gee, Maurice. Nelson Central School: A History. Nelson: Nelson Central School Centennial Committee, 1978.

Mann, Shohadh. F.G. Gibbs: His Influence on the Social History of Nelson, 189o195. Nelson: The Nelson Historical Society, 1977.

O' Brien, Gregory. 'Making Sentences Work'. Moments of Invention: Portraits of 21 New Zealand Writers. Auckland: Heinemann Reed, 1988.

Sargeson, Frank. 'An Affair of the Heart'. The Stories of Frank Sargeson. Auckland: Penguin Books, 1982, 43-51. 
van Rij, Vivien. 'Interview with Maurice Gee'. Wellington: 9 December, 2003, unpublished.

Wattie, Nelson. 'Maurice Gee'. The Oxford Companion to New Zealand Literature. Eds Roger Robinson and Nelson Wattie. Auckland: Auckland University Press, 1998.

\section{ENDNOTES}

${ }^{1}$ Maurice Gee, Nelson Central School: A History (Nelson: Nelson Central School Centennial Committee, 1978). Further references to the school history draw on this publication.

2 Maurice Gee, The Fire-Raiser (Auckland: Puffin Books, 2003). Subsequent quotations from The Fire-Raiser draw on this edition.

3 In Chapter Three of The Fire-Raiser Mrs Marwick states, 'This land has been mine for fifty years' (40). Presumably acquiring the property upon marriage at about twenty years of age in approximately 1865, Mrs Marwick would have been born around 1845, making the date of her immigration about 1855 . 